\title{
Expansion of Hand Hygiene Compliance and Decreasing Counterfeiting of Sanitation Products in the Era of the COVID-19 through Diversification and Standardization of Alcohol-Based Gel and Wipes Hand Sanitizer
}

\author{
N. Kusumawati ${ }^{a,}$, Pirim Setiarso a, Agus Budi Santoso ${ }^{b}$, Supari Muslim ${ }^{\text {b }}$ \\ ${ }^{a}$ Departement of Chemistry, Universitas Negeri Surabaya, Ketintang, Surabaya, 60231, Indonesia \\ ${ }^{b}$ Departement of Electrical Engineering, Universitas Negeri Surabaya, Ketintang, Surabaya, 60231, Indonesia \\ Corresponding author: "nitakusumawati@unesa.ac.id
}

\begin{abstract}
The increasing cases of infection and the number of deaths triggered by COVID-19 make all prevention and treatment efforts urgent. Increased discipline to maintain hand hygiene must be sought immediately to break the chain of its spread. The availability of alcohol-based hand sanitizer products with various specifications is needed to ensure increased discipline in hand hygiene. This study carried out the diversification of alcohol-based hand sanitizers by varying the active ingredients and preparations. The effect of alcohol on the characteristics and anti-microbial activity of the gel and wipe hand sanitizer products was studied to obtain optimal benefits. The best hand sanitizer characteristics are shown in gel formulation 3 with bioethanol as an active ingredient, which has pH 5.88, good homogeneity, density $0.95 \mathrm{~g} / \mathrm{cm}^{3}$, viscosity $2783.69 \mathrm{cPs}$, dispersibility $5.16 \mathrm{~cm}$, adhesion $3.21 \mathrm{~s}$, and dry time $29.27 \mathrm{~s}$. While the best formulation of wipe hand sanitizer produced by formulation 3 made from bioethanol has a pH of 6.14 , good homogeneity, density $0.86 \mathrm{~g} / \mathrm{cm}^{3}$, viscosity $2.812 \mathrm{cPs}$, spreadability $15.34 \mathrm{~cm}$, adhesion $1.92 \mathrm{~s}$, and dry time $18.20 \mathrm{~s}$. The biological activity test results of the two best hand sanitizer formulations, gel, and wipe preparations, showed good anti-microbial activity against Escherichia coli, Staphylococcus aureus, and Salmonella. In addition, the two preparations of hand sanitizer products were also detected to have good stability characteristics up to 4 weeks of storage time.
\end{abstract}

Keywords-Hand sanitizer; alcohol; gel, wipe; antimicrobial.

Manuscript received 9 Dec. 2020; revised 29 Jan. 2021; accepted 13 Apr. 2021. Date of publication 28 Feb. 2022. IJASEIT is licensed under a Creative Commons Attribution-Share Alike 4.0 International License.

\section{INTRODUCTION}

The emergence of new pathogens, whether bacteria or viruses, has always been a challenge for people worldwide. One of these dangerous pathogens is "severe acute respiratory syndrome coronavirus 2" (SARS-CoV-2), which causes COVID-19 [1]. In its development, until November 2020, SARS-CoV-2 resulted in 55 million cases of infection with death, more than 1.3 million people worldwide [2], [3]. With cases of infection and death continuing to increase, serious efforts must be made to address them. The absence of an effective treatment for this virus has made prevention efforts possible to overcome the health problems triggered by COVID-19. In this regard, the Center for Disease Control and Prevention (CDC) recommends routine hand cleaning as an effort to prevent the transmission of COVID-19 [4]. The general public is recommended to keep their hands clean by washing their hands in running water with soap. This can be a problem for people in areas with minimal access to clean water. In this case, the use of alcohol-based hand sanitizers is a popular alternative.

Alcohol-based hand sanitizers are capable of generating broad-spectrum anti-microbial activity in a short time [2], [5]-[8]. The content of $62 \%-90 \%$ alcohol effectively kills bacteria, fungi, or viruses through the denaturation of microbial proteins [5], [9]. This product can be made from propanol, isopropanol, and ethanol. However, the cause of simplicity, effectiveness and less time lead to high demand for ethanol-based hand sanitizers (EBHS) [5]-[7]. The increasing popularity of EBHS in preventing COVID-19 poses significant risks to public health, from lack of market availability due to stockpiling to counterfeiting. There are two types of EBHS adulteration: the content of the active ingredients replaced by methanol [2], [8], and the ethanol 
content of below $60 \%$. Methanol should not be used as a hand sanitizer because it causes systemic toxicity and death [8][16]. Meanwhile, the ethanol content of less than $60 \%$ does not have a biocidal effect, so unwittingly, it makes the public vulnerable to the spread of COVID-19. These various conditions can be overcome, one of which is through formulation standardization of hand sanitizers based on isopropanol and bioethanol as well as a combination of both, to produce HS with characteristics similar to EBHS. This effort is expected to increase the availability of HS products which are alternatives in the market. Thus, counterfeiting of EBHS products can be suppressed.

Washing hands with HS, can reduce transient virus levels, either through non-activation or by physically removing the virus from the skin. The relative efficacy of this method has not been sufficiently studied. While an early study reported the use of wet wipes with alcohol content had no better properties against bacteria than ordinary wet wipes, nonantimicrobial soap, and water, due to the low volume and concentration of alcohol in the wipes [17]. However, the effect of active compounds isopropanol and bioethanol has not been reported using their combinations, higher concentrations in tissue, and comparison of the effectiveness of hand sanitizer gels and wipes in health care settings [18]. Therefore, this research aims to obtain alcohol-based hand sanitizer formulations and preparations that have high antimicrobial activity and have various advantages in use, such as acceptable adhesion and fast dry time. The increasing variety of alcohol-based hand sanitizer products on the market is expected to increase discipline in maintaining hand hygiene while reducing the level of counterfeiting sanitary products.

\section{MATERIALS AND METHOD}

\section{A. Material}

The manufacture of gel hand sanitizer uses a number of ingredients, such as carbomers (Carbopol-940, ChemindoIndonesia) and triethanolamine (TEA) (>98\%, Merck) which are used as gel preparations, as well as glycerol 98\%, MerckIndonesia) and isopropyl myristate (IPM) (98\%, SigmaAldrich-Australia) and alcohol which is used as the main component of both types of hand sanitizer preparations. Alcohol's active ingredients used for sanitation products include ethanol (96\%, Sigma-Aldrich-Australia), bioethanol (96\%, Merck-Indonesia), and isopropanol ( $\geq 99.8 \%$, SigmaAldrich-Australia). Coffee essential oil (100\%) is added from Natural Pedia (India) to give a pleasant aroma. Specifically, making a hand sanitizer wipe only uses the main components (Table 4). This research was conducted following a systematic stage, as shown in Figure 1.

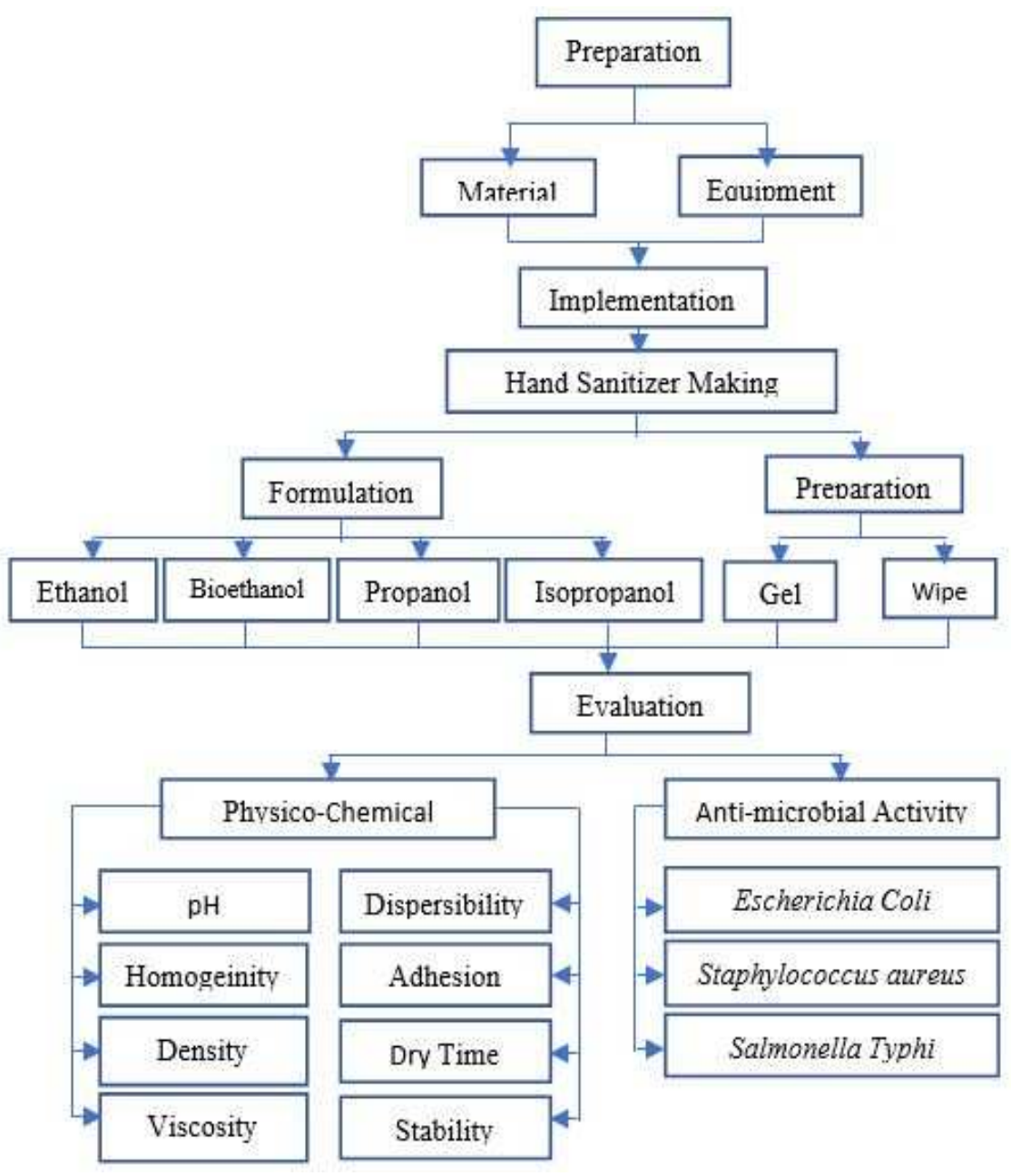

Fig. 1 Research systematic stage 


\section{B. Making of Gel Hand Sanitizer}

Making gel hand sanitizer includes three stages: forming a gel base, mixing active ingredients, and making hand sanitizer products. The gel base was prepared by dissolving $0.38 \%$ carbomer in $16.915 \%$ distilled water which had been heated to a temperature of $80{ }^{\circ} \mathrm{C}$. Stirring is carried out until a gel basis is formed. To condition the $\mathrm{pH}, 0.095 \%$ triethanolamine (TEA) was added to it and stirred until it was homogeneous. In the second stage, $11.65 \%$ glycerin and $0.77 \%$ isopropyl myristate (IPM) were added to the active ingredient of $70 \%$ alcohol and stirred until homogeneous. The active alcoholic ingredient is then added gradually to the gel basis, accompanied by stirring using a magnetic stirrer at a speed of $1000 \mathrm{rpm}$ for 30 minutes. To give a pleasant aroma, $0.19 \%$ Coffea essential oil is added to the gel hand sanitizer.

\section{Making of Wipes Hand Sanitizer}

The manufacture of wipes hand sanitizer includes two stages: the manufacture of hand sanitizer fluid and the manufacture of wipe hand sanitizer. To obtain hand sanitizer fluid, $11.65 \%$ glycerin is added on a $70 \%$ alcohol basis. Stirring is done until all the glycerin is evenly mixed in the alcohol base. Subsequently, 0.77\% IPM, 17.39\% aquadest and $0.19 \%$ essential oil were added. Stirring is applied until all ingredients are homogeneously mixed in the alcohol base. Five hundred milliliters of hand sanitizer liquid are then poured evenly over the entire surface of the 100 sheets of tissue material that have been placed in a vacuum and then closed tightly. To ensure that the entire surface of the tissue has been coated with hand sanitizer liquid, leave the tissue for 24 hours at a temperature of $5{ }^{\circ} \mathrm{C}$.

\section{Quality Determination}

To obtain the quality of hand sanitizer products, a number of tests were carried out, including $\mathrm{pH}$, homogeneity, density, viscosity, dispersibility, adhesion, dry time, and stability.

1) $\mathrm{pH}$

- Gel hand sanitizer. One gram of hand sanitizer gel is diluted using $10 \mathrm{~mL}$ of distilled water and stirred until homogeneous. The solution is then measured using a Mi-150 pH meter.

- Wipes hand sanitizer. Ten milliliters of liquid obtained from the wipe hand sanitizer were measured using a $\mathrm{pH}$ meter.

2) Homogeneity: The same procedure carried out the homogeneity measurement of gel and wipe hand sanitizer. One gram of gel hand sanitizer or $1 \mathrm{~g}$ of liquid from the wipe hand sanitizer is placed on a petri dish to observe the sampling results in 3 parts: top, middle, and bottom. Good homogeneity is indicated in the absence of coarse grains.

3) Density: Density measurement is done using a pycnometer (Pyrex-Iwaki). The gel hand sanitizer and the liquid produced from the wipe hand sanitizer are put into the pycnometer until it reaches the limit mark, then weighed using OHAUS PA224 analytical balance. The resulting density is calculated using equation (1).

$$
\text { Density }\left(\mathrm{g} / \mathrm{cm}^{3}\right)=\frac{\text { Pycnometer and sample mass }- \text { Pycnometer mass }}{\text { Pycnometer volume }}
$$

4) Viscosity: The viscosity measurement of gel and wipes hand sanitizer was carried out with the same procedure using 002-7580 Thermo Scientific Falling ball Viscometer. Specifically, the sample is filled until the tube is filled, and then the ball is inserted into it according to the measured sample viscosity. The higher the viscosity level, the greater the density and ball constant used. In Table 1, the ball density sequence on the viscometer measurement is shown.

TABLE I

LIST OF BALL SEQUENCES ON THE THERMO SCIENTIFIC FALLING BALL VISCOMETER

\begin{tabular}{llll}
\hline No & Material & $\begin{array}{l}\text { Density } \\
\left(\mathbf{g} / \mathbf{c m}^{\mathbf{3}}\right)\end{array}$ & K \\
\hline 1. & Boron Sillica Glass & 2.2 & 0.007 \\
2. & Boron Sillica Glass & 2.2 & 0.09 \\
3. & Nickel Iron Alloy & 8.1 & 0.09 \\
4. & Nickel Iron Alloy & 8.1 & 0.7 \\
5. & W.-No. 4304 & $7.7-8.1$ & 4.5 \\
6. & W.-No. 4304 & $7.7-8.1$ & 33 \\
\hline
\end{tabular}

The viscosity of the test results is calculated using equation 2 .

$$
\eta=\mathrm{K}\left(\rho_{1}-\rho_{2}\right) \mathrm{t}
$$

Where, $\eta$ is sample viscosity (mPa.s); $\mathrm{K}$ is the ball constant $\left(\mathrm{mPa} . \mathrm{s} . \mathrm{cm}^{3} / \mathrm{g} . \mathrm{s}\right) ; \rho_{1}=$ ball density $\left(\mathrm{g} / \mathrm{cm}^{3}\right) ; \rho_{2}=$ sample density $\left(\mathrm{g} / \mathrm{cm}^{3}\right) ; t=$ travel time ball (s).

5) Dispersibility: For dispersibility determination, use 2 pieces of square glass of the same size. A line is drawn using a pencil and ruler on each glass until it meets the center point. Half a gram of gel hand sanitizer and liquid from wipes hand sanitizer is placed right at the center of the glass, then covered with another glass for one minute. The diameter of the gel and liquid distribution at 4 points was measured to get the average value. Then on top of the cover glass, a load of $50 \mathrm{~g}$ is placed, let stand for 1 minute, and then the diameter of the spread is measured. The same procedure was carried out for additional loads of $100,150,200,250$, and $300 \mathrm{~g}$, and then the average gel and liquid spread diameter was calculated. In Table 2, the gel and liquid wipe hand sanitizer dispersibility test sheet is presented, which is then calculated using equation (3).

TABLE II

GEL AND LIQUID WIPES HAND SANITIZER DISPERSIBILITY TEST SHEET

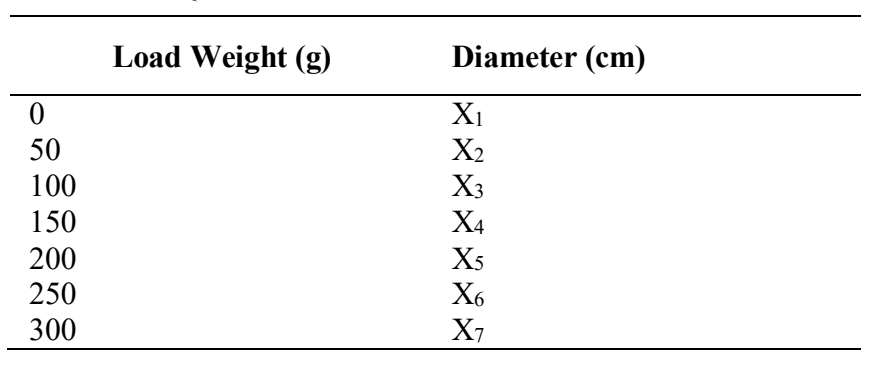

$$
\text { Dispersibility }=\frac{X_{1}+X_{2}+X_{3}+X_{4}+X_{5}+X_{6}+X_{7}}{7}
$$

6) Adhesion: The adhesion determination of the gel and wipe hand sanitizer products is carried out using the same procedure. The test is carried out using a pair of slides (A and B) which are clamped and given a rope connected to the weights at both ends. A quarter of a gram of hand sanitizer gel 
is placed on glass A and on top of it is placed glass B. On the top of glass $\mathrm{B}$, a load of $1 \mathrm{~kg}$ is given for 5 minutes to ensure that the hand sanitizer adheres perfectly. The tip of glass A was given a load of $1 \mathrm{~kg}$, while the tip of glass B was given a load of $80 \mathrm{~g}$. The $80 \mathrm{~g}$ load is then removed, and the time required for the two glasses to come off was calculated.

7) Dry time: The drying time test for the gel and wipe hand sanitizer was carried out using the same procedure. Fifty $\mathrm{mg}$ of gel or wipe hand sanitizer is rubbed on the hands with an area of $2 \mathrm{~cm}^{2}$. The spread of gel and liquid from the hand sanitizer wipe is smoothed using a spatula for 5 seconds, and then the dry time is calculated using a stopwatch.

8) Stability: To determine the stability of gel and wipe hand sanitizer products, tests were carried out on $\mathrm{pH}$, homogeneity, density, viscosity, dispersibility, adhesion, and dry time from week 1 to week 10 .

9) Anti-microbial activity: The gel and wipe hand sanitizer products' antibacterial activity was evaluated using the liquid diffusion method. This method measures the presence or absence of colony growth to know the presence or absence of bacterial activity. The method used was to prepare the bacterial inoculum by measuring the transmittance on a spectrophotometer at a wavelength of 580 $\mathrm{nm}$ until $25 \%$ transmittance was obtained, making a $19800 \mu \mathrm{L}$ nutrient broth solution in a tube and then adding $200 \mu \mathrm{l}$ of bacterial inoculum in each tube. The next step is to put $2 \mathrm{ml}$ of the sample into the tube and then add $200 \mu \mathrm{l}$ of nutrient broth solution, which has been added with the bacterial inoculum (3 times replication). $2 \mathrm{ml}$ of sterile water was also made then added with $200 \mu \mathrm{l}$ of nutrient broth solution which had been added to the inoculum as a negative control in a different tube. The next step was to make a $100 \mathrm{ppm}$ streptomycin solution which was put in the tube and then added $200 \mu 1$ of nutrient broth solution, which had been added with the bacterial inoculum as a positive control. This was followed by incubation the sample at $32.5^{\circ} \mathrm{C}$ for $18-24$ hours for 24 hours and observed growth. If the solution in the tube is cloudy, there is bacterial growth. If the observation is in doubt, take $1 \mathrm{ml}$ of the sample and put it in a Petri with a diameter of $9 \mathrm{~cm}$ then pour the nutrient media so that what has been diluted and has a temperature of $\pm 40^{\circ} \mathrm{C}$ as much as \pm 15 $\mathrm{mL}$, let it cool and solidify. The next step was incubation in the incubator at $32.5^{\circ} \mathrm{C}$ for 24 hours. After the incubation period, the sample is removed from the incubator and then observes the Petri whether there is colony growth or not.

\section{RESULTS AND DISCUSSION}

\section{A. Making Hand Sanitizer}

The making of gel and wipe hand sanitizer follows the formulation shown in Table 3. The procedure for making gel hand sanitizer is divided into three stages. The first stage is forming a gel base from the carbomer and TEA. Carbomers act as gelling water-soluble polymers. Its stable and hygroscopic nature as well as soluble in water, alcohol, and glycerin, make this gelling agent widely used in semi-solid product formulations [19]. Furthermore, carbomer is also known to have the advantage of having a clear gel appearance (transparent) with good texture and stability. This material also readily binds water but is slow in releasing liquids [20].
In the formulation, distilled water is not only used to dissolve carbomers but also to dilute the active ingredients of alcohol which are required for denaturing the proteins of microorganisms [5], [21], [22].

Triethanolamine (TEA) is responsible as a $\mathrm{pH}$ regulator and stabilizer in hand sanitizer formulations [21], [23]. This material has a $\mathrm{pH}$ of 10.5 and dissolves in water, methanol, carbon tetrachloride, and acetone [24]. In the gel formulation, the effective and stable concentration of TEA to neutralize $\mathrm{pH}$ and carbomer-based purification was $1 \% \mathrm{w} / \mathrm{v}$. The interaction of hydrogen bond formation between the carbomer and TEA is thought to be mediated by the hydroxyl group (-OH) on TEA and the carbonyl group $(\mathrm{C}=\mathrm{O})$ on the gelling agent (carbomer) [20]. The more hydrogen bonds there are, the stronger the bonds formed so that the viscosity is higher.

TABLE III

THE FORMULATION OF GEL HAND SANITIZER

\begin{tabular}{|c|c|c|c|c|c|c|}
\hline Material & G1 & G2 & G3 & G4 & G5 & G6 \\
\hline Ethanol (g) & 21 & 0 & 0 & 8.4 & 0 & 12.6 \\
\hline $\begin{array}{l}\text { Isopropano } \\
1(\mathrm{~g})\end{array}$ & 0 & 21 & 0 & 0 & 8.4 & 8.4 \\
\hline $\begin{array}{l}\text { Bioethanol } \\
\text { (g) }\end{array}$ & 0 & 0 & 21 & 12.6 & 12.6 & 0 \\
\hline $\begin{array}{l}\text { Carbomer } \\
\text { (g) }\end{array}$ & 0.114 & 0.114 & 0.114 & 0.114 & 0.114 & 0.114 \\
\hline TEA (g) & $\begin{array}{l}0.028 \\
5\end{array}$ & $\begin{array}{l}0.028 \\
5\end{array}$ & $\begin{array}{l}0.028 \\
5\end{array}$ & $\begin{array}{l}0.028 \\
5\end{array}$ & $\begin{array}{l}0.028 \\
5\end{array}$ & $\begin{array}{l}0.028 \\
5\end{array}$ \\
\hline $\begin{array}{l}\text { Glyserin } \\
\text { (g) }\end{array}$ & 3.465 & 3.465 & 3.465 & 3.465 & 3.465 & 3.465 \\
\hline IPM (g) & 0.231 & 0.231 & 0.231 & 0.231 & 0.231 & 0.231 \\
\hline $\begin{array}{l}\text { Essential } \\
\text { oil }(\mathrm{g})\end{array}$ & 0.057 & 0.057 & 0.057 & 0.057 & 0.057 & 0.057 \\
\hline $\begin{array}{l}\text { Aquadest } \\
\text { (g) }\end{array}$ & $\begin{array}{l}5.074 \\
5\end{array}$ & $\begin{array}{l}5.074 \\
5\end{array}$ & $\begin{array}{l}5.074 \\
5\end{array}$ & $\begin{array}{l}5.074 \\
5\end{array}$ & $\begin{array}{l}5.074 \\
5\end{array}$ & $\begin{array}{l}5.074 \\
5\end{array}$ \\
\hline
\end{tabular}

TABLE IV

THE FORMULATION OF WIPE HAND SANITIZER

\begin{tabular}{|c|c|c|c|c|c|c|}
\hline Material & W1 & W2 & W3 & W4 & W5 & W6 \\
\hline Ethanol (g) & 21 & 0 & 0 & 8.4 & 0 & 12.6 \\
\hline $\begin{array}{l}\text { Isopropanol } \\
\text { (g) }\end{array}$ & 0 & 21 & 0 & 0 & 8.4 & 8.4 \\
\hline $\begin{array}{l}\text { Bioethanol } \\
\text { (g) }\end{array}$ & 0 & 0 & 21 & 12.6 & 12.6 & 0 \\
\hline Carbomer (g) & 0 & 0 & 0 & 0 & 0 & 0 \\
\hline TEA $(\mathrm{g})$ & 0 & 0 & 0 & 0 & 0 & 0 \\
\hline Glyserin (g) & 3.495 & 3.495 & 3.495 & 3.495 & 3.495 & 3.495 \\
\hline IPM (g) & 0.231 & 0.231 & 0.231 & 0.231 & 0.231 & 0.231 \\
\hline $\begin{array}{l}\text { Essential oil } \\
\text { (g) }\end{array}$ & 0.057 & 0.057 & 0.057 & 0.057 & 0.057 & 0.057 \\
\hline Aquadest (g) & 5.217 & 5.217 & 5.217 & 5.217 & 5.217 & 5.217 \\
\hline
\end{tabular}

The second stage is making a mixture of the active ingredients alcohol (ethanol, isopropanol, and bioethanol) with glycerin and IPM. Glycerin functions as an emollient or moisturizer that counteracts the negative effects of alcohol which can trigger dry and irritated skin due to astringent absorption [23], [25]. Emollients also increase antibacterial activity by slowing down the drying time or extending the deposition time of alcohol on the skin surface [22]. Ethanol, isopropanol and bioethanol have a role as active ingredients with a germicidal activity that can kill microorganisms such as bacteria, fungi, or viruses through protein denaturation, while IPM is a non-greasy softener that is easily absorbed by the skin. This material is used as a base for semi-solid products [26], [27]. 
The third stage is the manufacture of hand-sanitizer gel by adding active ingredients to the gel base. The addition of coffea essential oil to gel hand sanitizer products functions as a fragrance agent and as an antioxidant and anti-microbial agent [23], [28]. Specifically, the manufacture of wipe hand sanitizer products follows the same procedure, but without the addition of carbomer and TEA. Hand sanitizer liquid that already contains active ingredients of alcohol, glycerin, IPM, essential oil, and aqua dest is then poured evenly on the wipe from spunlace nonwoven fabric, generally used as raw material for wet tissue products. Furthermore, the wipe hand sanitizer products are stored at a temperature of $5^{\circ} \mathrm{C}$ for 24 hours to ensure the homogeneity of the sanitizer fluid on the wipe material.

\section{B. $p H$}

The viralidal effect of ethanol-based hand sanitizer against Norovirus (NoV) was reported to be increased at neutral $\mathrm{pH}$ [29], while Park et al. (2010) reported an increase in viralidal effectiveness along with a decrease in $\mathrm{pH}$ from 7.4 to 3 . However, because direct contact with the skin takes place intensively, especially during the current COVID-19 epidemic, hand sanitizer products must be ensured to have the appropriate $\mathrm{pH}$ or closer to the $\mathrm{pH}$ of the skin, namely 4.5-6.5 [30]. A pH value that is too acidic can cause skin irritation, while a $\mathrm{pH}$ that is too alkaline can lead to the appearance of scaly skin [31]. Table 5 and Table 6 respectively show the $\mathrm{pH}$ values of six gel and wipe hand sanitizer product formulations.

TABLE V

GEL HAND SANITIZER PH

\begin{tabular}{|c|c|c|c|c|c|c|}
\hline Parameter & G1 & G2 & G3 & G4 & G5 & G6 \\
\hline \multirow{2}{*}{$\begin{array}{l}\mathrm{pH} \\
\text { Homogeneity }\end{array}$} & 5.95 & 5.98 & 5.88 & 6.06 & 5.90 & 5.86 \\
\hline & 之 & 之 & 乙 & 乙 & 之 & 乙 \\
\hline Density $\left(\mathrm{g} / \mathrm{cm}^{3}\right)$ & 0.83 & 0.88 & 0.95 & 0.82 & 0.85 & 0.86 \\
\hline Viscosity (cPs) & 2.225 & 2.026 & 2.783 & 2.172 & 2.521 & 2.130 \\
\hline $\begin{array}{l}\text { Dispersi- bility } \\
(\mathrm{cm})\end{array}$ & 5.37 & 6.05 & 5.16 & 5.54 & 5.26 & 5.81 \\
\hline Adhesion (s) & 2.33 & 1.95 & 3.21 & 2.17 & 2.19 & 2.05 \\
\hline $\begin{array}{l}\text { Dry Time } \\
\text { (s) }\end{array}$ & 23.25 & 27.65 & 29.27 & 23.19 & 20.87 & 25.64 \\
\hline
\end{tabular}

Table 5 shows that, in general, all hand sanitizer gel product formulations produced have a $\mathrm{pH}$ value in the range 5.88-6.0. In line with this, the six wipe hand sanitizer formulations had a $\mathrm{pH}$ in the range 6.07-6.99, as shown in Table 6. Thus, all gel and wipe hand sanitizer formulations are safe to use because they have a $\mathrm{pH}$ in the skin-tolerant $\mathrm{pH}$ range, namely 4.5-7.5 [30], [31]. Specifically, gel hand sanitizer has a lower $\mathrm{pH}$ range than wipe hand sanitizer products. This is a consequence of the reaction between the carbomer and the alcohol, resulting in a mixed $\mathrm{pH}$ of 5.86 [32], [33]. The type of alcohol did not significantly affect the $\mathrm{pH}$ value of the gel and wipe hand sanitizer product.

\section{Homogeinity}

The homogeneity test was carried out to observe the evenness of the gel and hand sanitizer fluid distribution from the wipe. However, the presence of the homogeneity test plays a more significant role in the gel than the wipe hand sanitizer product because the liquid base in the wipe hand sanitizer product has a much lower level of mixing difficulty than the gel base. The low particle density of the liquid base in the wipes hand sanitizer makes it easier for other particles to enter so that they reach homogeneous mixing conditions faster than on a gel base. Specifically, a good gel must meet the requirements of SNI No. 06-2588-1992, which does not have coarse grains or lumps [34]. Based on the data from the homogeneity test results, as shown in Table 5, all hand sanitizer gel formulations showed good gel homogeneity, which was indicated by the uniform dispersion of the gel or not observing the formation of granules on one side. Meanwhile, according to initial predictions, all formulations of wipe hand sanitizer products have excellent homogeneity, much better than hand sanitizer gels (see Table 6).

TABLE VI

WIPE HAND SANITIZER PH

\begin{tabular}{|c|c|c|c|c|c|c|}
\hline Parameter & W1 & W2 & W3 & W4 & W5 & W6 \\
\hline \multirow{2}{*}{$\begin{array}{l}\mathrm{PH} \\
\text { Homogeneity }\end{array}$} & 6.99 & 6.39 & 6.14 & 6.07 & 6.26 & 6.47 \\
\hline & 乙 & 乙 & そ & そ & 乙 & 之 \\
\hline Density $\mathrm{g}\left(\mathrm{g} / \mathrm{cm}^{3}\right)$ & 0.83 & 0.82 & 0.86 & 0.87 & 0.84 & 0.83 \\
\hline Viscosity (cPs) & 2.696 & 4.076 & 2.812 & 3.109 & 3.604 & 3.201 \\
\hline $\begin{array}{l}\text { Dispersi-bility } \\
(\mathrm{cm})\end{array}$ & 16.09 & 11.39 & 15.34 & 14.46 & 13.54 & 13.95 \\
\hline Adhesion (s) & 1.12 & 2.66 & 1.92 & 1.41 & 2.19 & 1.14 \\
\hline Dry Time (s) & 18.52 & 16.31 & 18.2 & 22.42 & 24.16 & 20.55 \\
\hline
\end{tabular}

\section{Density}

Based on Table 5 and Table 6, shows that the gel hand sanitizer product has a density in the range $0.82-0.95 \mathrm{~g} / \mathrm{cm}^{3}$, while the wipe hand sanitizer product is in the range 0.82 $0.87 \mathrm{~g} / \mathrm{cm}^{3}$. Specifically, among the six formulations in the manufacture of gel hand sanitizer, formulation 3 with the active ingredient bioethanol produced the highest density, which was $0.95 \mathrm{~g} / \mathrm{cm}^{3}$, while formulation 4 with the active ingredient from a combination of ethanol and bioethanol produced the lowest density, which was equal to $0,82 \mathrm{~g} / \mathrm{cm}^{3}$. Meanwhile, for the wipe hand sanitizer, formulation 4 with the active ingredient from a combination of ethanol and bioethanol produced the highest density, $0.87 \mathrm{~g} / \mathrm{cm}^{3}$, while formulation 2 with the active ingredient isopropanol produced the lowest density, which was $0.82 \mathrm{~g} / \mathrm{cm}^{3}$. The density test results of the six formulations, both from gel and wipe hand sanitizer, showed that the type of active ingredient affected the density of the hand sanitizer. However, there is a slight difference in the highest and lowest density yields for gel and wipe hand sanitizer products. This is predicted to be related to the reaction that occurs between the active ingredient (alcohol) the gelling agent (carbomer), and the $\mathrm{pH}$ controller (TEA) in the hand sanitizer gel product.

The characteristic properties of carbomers are influenced by the function of concentration, $\mathrm{pH}$, and crosslinking density. The selection of solvent for carbomers is an important factor because it affects the hydrogen bonds between water characteristics. Water solvents are widely used in dissolving carbomers with hydroalcoholic systems. Likewise, the addition of glycerin can modify the hydrogen bonds between water, solvents, and polymers so that it affects the swelling and viscoelasticity of the polymer. The addition of 
triethanolamine (TEA) to the gel formation system functions to neutralize the carboxylate groups of the polymer. In the neutralization process, microgel particles swell, forming a solid structure to form an elastic network. The entanglement between the long chains and the side chains of the microparticles of other compounds also influences the network structure [35], [36]. The swelling of the microgel to form a dense elastic structure with the effect of the addition of triethanolamine causes the polymerization reaction of carbomers.

\section{E. Viscosity}

Viscosity is an important parameter that must be considered when preparing hand sanitizer formulations, especially gel-based [37]. Gel hand sanitizers are thought to ensure disinfection can reach a wider surface area of the hands before evaporating with a small amount of dirt or residue. Gel that is too thin is easy to handle, but drips easily and leads to product inefficiency. Meanwhile, the gel that is too thick makes the evaporation process too long, leaving the user's hands in an oily condition for longer [38]. A good hand sanitizer must pay attention to disinfecting ability and practicality in use [39].

Accurate rheological measurements are the key to physical engineering characteristics that produce hand sanitizing gel products of the highest qualifications. The viscosity of the gel hand sanitizer product in this study is shown in Table 5. The results of the viscosity analysis on the six gel hand sanitizer formulations showed that the formulations 3 with the active ingredient bioethanol showed the highest viscosity $(2,783$ cPs), while the formulations 2 with the active ingredient isopropanol showed the opposite results, showed the lowest viscosities (2,026 cPs). The wipe hand sanitizer also showed similar results, where the highest viscosity $(4.076 \mathrm{cPs})$ was produced by the formulation 2 with the active ingredient isopropanol, while the lowest viscosity (2.696 cPs) was produced shown by the formulation 1 with the active ingredient ethanol.

The use of the right gelling agents is a major determinant of the viscosity of the formulation. A number of other factors also play a role, although not directly, in the final viscosity of the hand sanitizer product. Essential oils, for example, , even if added in small amounts, have the potential to change the behavior of the gel texture. However, the composition of all materials, excluding the alcohol, has been controlled in the manufacture of hand sanitizer products, both gels and wipes. The resulting viscosity is predicted to be influenced by the type of alcohol used. This is in line with the viscosity values of alcohol used in the manufacture of hand sanitizers in this study, namely ethanol of $1.317 \mathrm{cPs}$, isopropanol of $2.101 \mathrm{cPs}$, bioethanol of $1.452 \mathrm{cPs}$, bioethanol-ethanol $1.352 \mathrm{cPs}$, bioethanol-isopropanol $1.672 \mathrm{cPs}$, and ethanol-isopropanol $1.559 \mathrm{cPs}$ at $30^{\circ} \mathrm{C}$. The viscosity of hand sanitizer products can change due to the influence of temperature, humidity, and conditioning. Therefore, proper post-production handling is absolutely necessary to be able to maintain the targeted viscosity.

In gel formulations, the interaction between carbormer and alcohol is the main factor determining the viscosity of a handsanitizer preparation. In particular, the addition of the active alcohol ingredient in the form of isopropanol has decreased even though isopropanol has a higher viscosity than ethanol, which is $2.101 \mathrm{cPs}$. This occurs because of the presence of a methyl group as a side chain in isopropanol, a type of secondary alcohol, thereby reducing the possibility of other molecules approaching and affecting hydrogen bonding molecules. In addition, the effect of the bond between hydrogen alcohol and carbormer has an effect on the dehydrating effect of alcohol. Isopropanol has a lower hydrogen bond compared to ethanol so that the dehydration effect of alcohol on isopropanol is more dominant and has an impact on significantly reducing viscosity [40].

\section{F. Dispersibility}

The spreadability test was conducted to determine the ability of the hand sanitizer to spread on the skin surface. Semi-solid preparations are expected to have the ability to spread easily at the place of application, without significant pressure. The easier it is to apply to the skin, the more surface area the active ingredient contacts the skin. The results of the tests carried out showed that all gel hand sanitizer formulations were able to spread easily on the skin surface, which was indicated by the acquisition of the dispersion value in the range $5.16-6.05 \mathrm{~cm}$. This fact is supported by the acquisition of the dispersibility value that has met the dispersibility requirements for topical preparations (cream, lotion and ointment based), which is around $5-7 \mathrm{~cm} \mathrm{[41].} \mathrm{The}$ sanitizing fluid has generated a higher dispersive power value in the wipes hand sanitizer product. As shown in Table 6, the spreadability of the wipes hand sanitizer products is in the range $11.39-16.09 \mathrm{~cm}$.

Good dispersibility results in quick contact between the active ingredients of the hand sanitizer and the skin. The increase and decrease in spreadability is strongly influenced by the consistency of the gel, which is related to the viscosity value of the preparation. The high viscosity value of the preparation will result in a low spreadability area and vice versa. This happens because the high viscosity makes the gel difficult to flow so that the resulting spread area becomes small [42]. The lower viscosity compared to the gel hand sanitizer is what causes the wipes hand sanitizer product to have a much higher spreadability.

From the six formulations, it appears that the different types of alcohol as an active ingredient have had a significant effect on the change in the dispersibility of gels and wipes hand sanitizer, where the use of ethanol, isopropanol and bioethanol with viscosities which are consecutively increasing, has resulted in hand sanitizer products with lower dispersibility. Likewise, the formulation involves a combination of the active ingredient bioethanol with ethanol and isopropanol.

\section{G. Adhesion}

Adhesion describes the ability of gel and wipes hand sanitizer products to stick to the skin surface. The higher ability of hand sanitizer products to stick to the skin surface allows the active substance to provide a longer-lasting biological effect. The adhesion is directly proportional to the viscosity of the hand sanitizer product [43], [44]. The higher the viscosity of the hand sanitizer, the higher the adhesion. However, it should be noted that too strong adhesion will 
cover the skin pores, and if it is too weak, the sanitary effect will not be achieved [45], [46].

In the gel and wipes hand sanitizer products produced in this study, the variation of alcohol affects the viscosity of the preparation so that it affects its adhesion. As shown in Table 5 and Table 6 , the results of the adhesion analysis on the six formulation gel hand sanitizer the use of the active ingredient bioethanol produces a hand sanitizer product with a higher adhesion power of, which is $3.21 \mathrm{~s}$ compared to isopropanol and ethanol, which are $1.95 \mathrm{~s}$ and $2.33 \mathrm{~s}$ respectively. The dominance of the effect of bioethanol viscosity on adhesion is also observed from the adhesion of hand sanitizer products with active ingredients that combine bioethanol with ethanol and isopropanol. Wipe hand sanitizer the use of the active ingredient isopropanol produces a hand sanitizer product with a higher adhesion power of $2.26 \mathrm{~s}$ compared to ethanol and bioethanol, which are $1.12 \mathrm{~s} 1.92 \mathrm{~s}$ respectively. The adhesion ability of hand-sanitizer wipe preparations on the skin is based on the viscosity and dispersibility of the preparation, where the higher the viscosity, the more difficult the preparation is to flow or the greater its resistance [47].

\section{H. Dry Time}

Drying speed test shows the time required for each gel and wipes hand sanitizer formula to dry on the skin of the palms (front and back of the skin of the palms with an area of $2 \mathrm{~cm}^{2}$ ). Among the six gel hand sanitizer product formulations, the hand sanitizer with the active ingredient bioethanol takes the longest time to dry than the active ingredient ethanol and isopropanol and their combinations because of the viscosity of bioethanol is higher than other alcoholic active ingredients. On the other hand, gel hand sanitizer products made from a combination of bioethanol and isopropanol resulted in the shortest time to dry. The opposite result is shown by the wipe hand sanitizer product, where the W5 formulation with the active ingredient, which is a combination of bioethanol and isopropanol shows the longest drying time, while the W1 formulation with the active ingredient ethanol shows the fastest drying time. These results indicate that the viscosity resulting from the use of different types and compositions of alcohol-based active ingredients in manufacturing greatly affects the sanitary products' drying time. The higher the viscosity of the sanitary product, the slower the drying time of the hand sanitizer product. This fact is reinforced by the viscosity gain of each type and composition of the alcoholic ingredient previously described. All drying time results for gel hand sanitizer are shown in Table 5, while for wipe hand sanitizer products are shown in Table 6.

\section{Stability}

The results of the evaluation of $\mathrm{pH}$, homogeneity, density, viscosity, dispersibility, adhesion, and dry time of the six gel and hand sanitizer product formulations from week 1 to week 4 showed fairly high stability at room temperature $\left( \pm 30^{\circ} \mathrm{C}\right)$. The $\mathrm{pH}$, homogeneity, density, viscosity, dispersibility, adhesion, and dry time values in the first to the tenth week are shown in Fig. 2 - Fig. 7 for gel hand sanitizer and Fig. 8 - Fig. 13 for wipe hand sanitizer.

The $\mathrm{pH}$ stability of the gel and wipe hand sanitizer products was indicated by a shift in the $\mathrm{pH}$ value for 10 weeks at room temperature storage $\left( \pm 30^{\circ} \mathrm{C}\right)$. Based on the data in Table 7 , it was found that there was no detectable decrease in the $\mathrm{pH}$ until the third week. Meanwhile, after the $10^{\text {th }}$ week, a decrease in $\mathrm{pH}$ was detected respectively by 5.91, 5.92, 5.84, $6.01,5.85$, and 5.82 for commercial products, formulation 1 , $2,3,4,5$, and 6 for gel hand sanitizer and amounting to 6.25 , $6.34,6.42,6.48,6.60$ and 6.57 for commercial products, formulation $1,2,3,4,5$, and 6 on wipe hand sanitizer products. However, the decrease that occurred was not significant, and the $\mathrm{pH}$ value obtained was still within the skin $\mathrm{pH}$ range, which was 4.5-6.5. This is predicted to occur due to the hydrolysis process triggered by room temperature. This condition further lowers the $\mathrm{pH}$. These results are in line with those reported in a number of publications [48][49]. Thus, storing gel and wiping hand sanitizer in a place that is not exposed to direct sunlight is absolutely necessary.

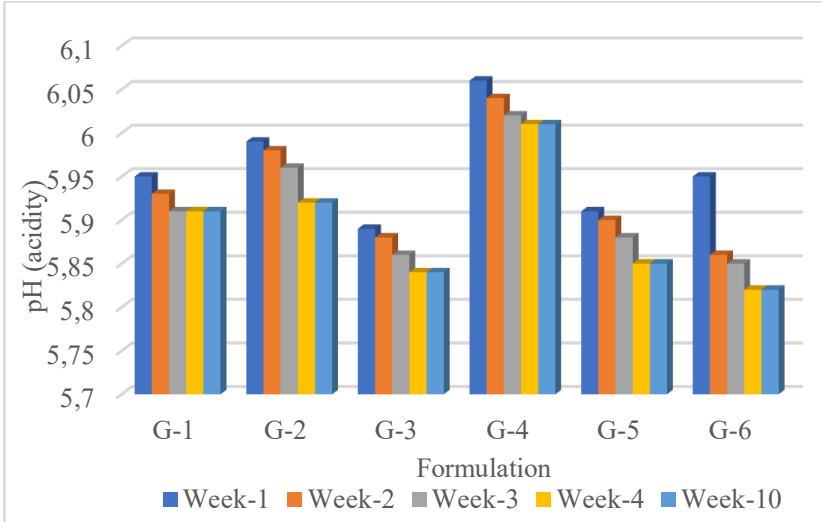

Fig. $2 \mathrm{pH}$ stability of the gel hand sanitizer

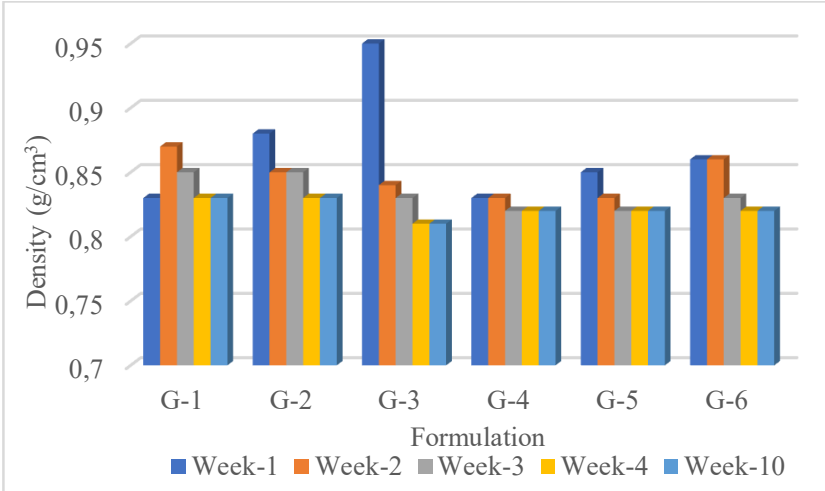

Fig. 3 Density stability of the gel hand sanitizer

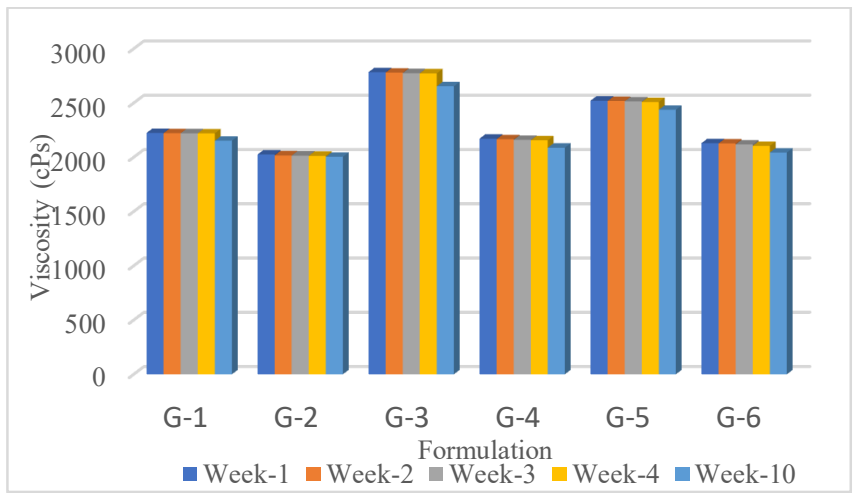

Fig. 4 Viscosity stability of the gel hand sanitizer 


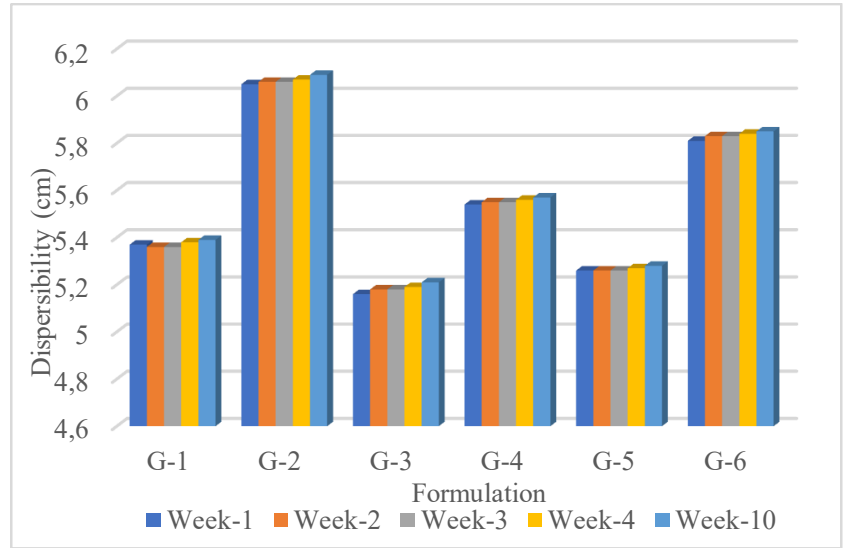

Fig. 5 Dispersibility stability of the gel hand sanitizer

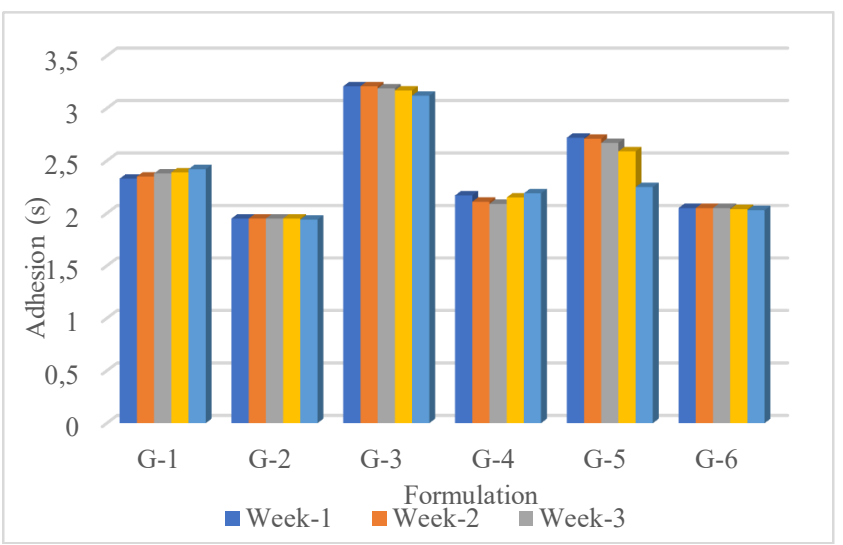

Fig. 6 Adhesion stability of the gel hand sanitizer

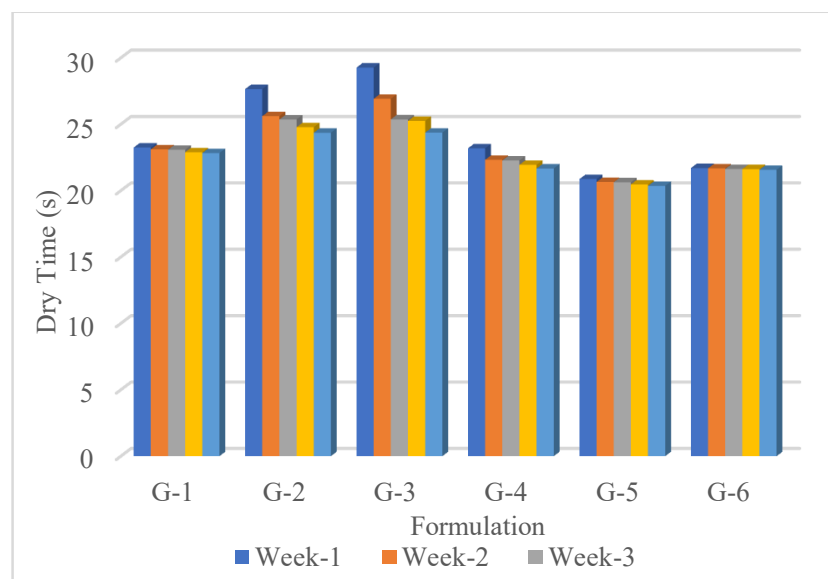

Fig. 7 Dry time stability of the gel hand sanitizer

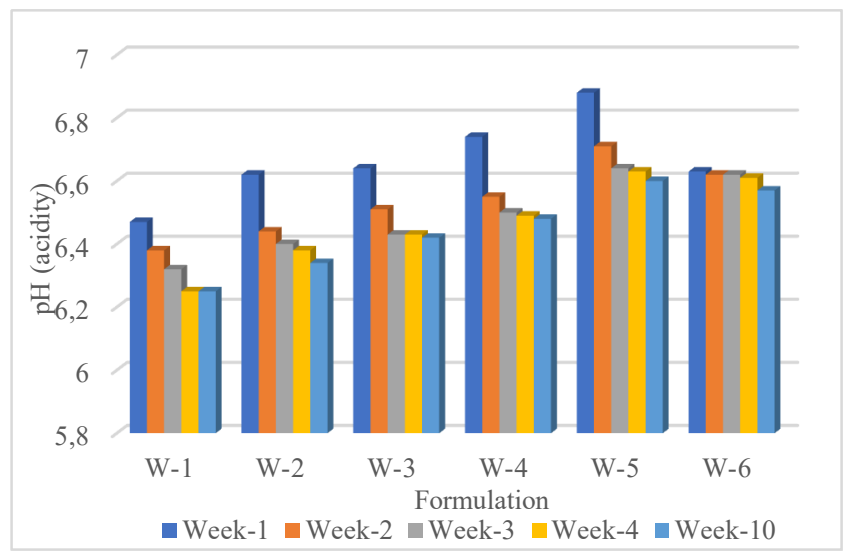

Fig. $8 \mathrm{pH}$ stability of the wipe hand sanitizer

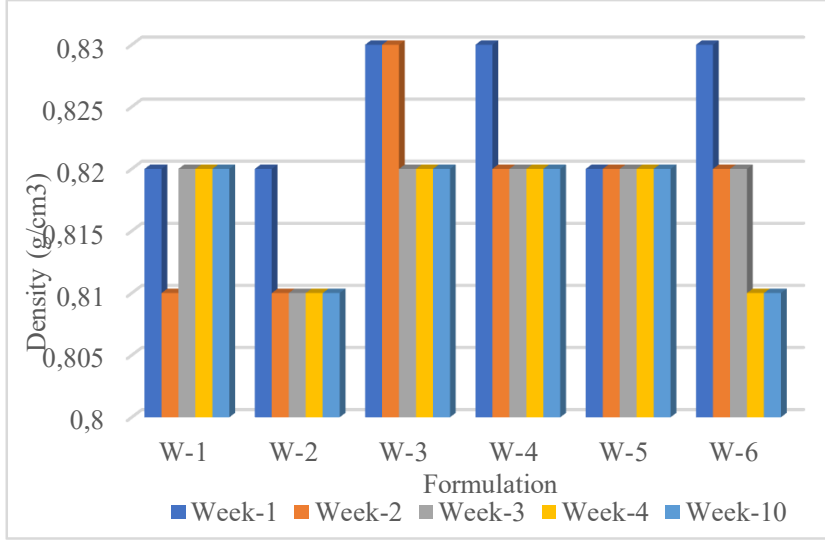

Fig. 9 Density stability of the wipe hand sanitizer

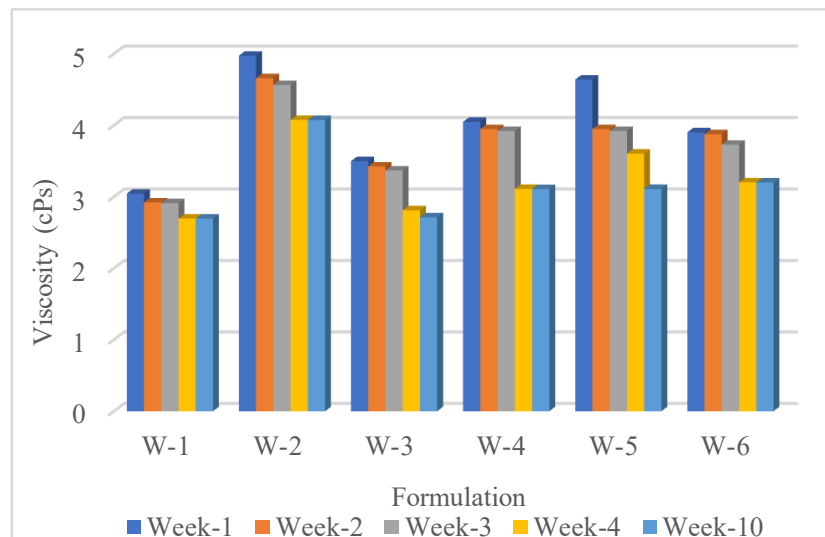

Fig. 10 Viscosity stability of the wipe hand sanitizer

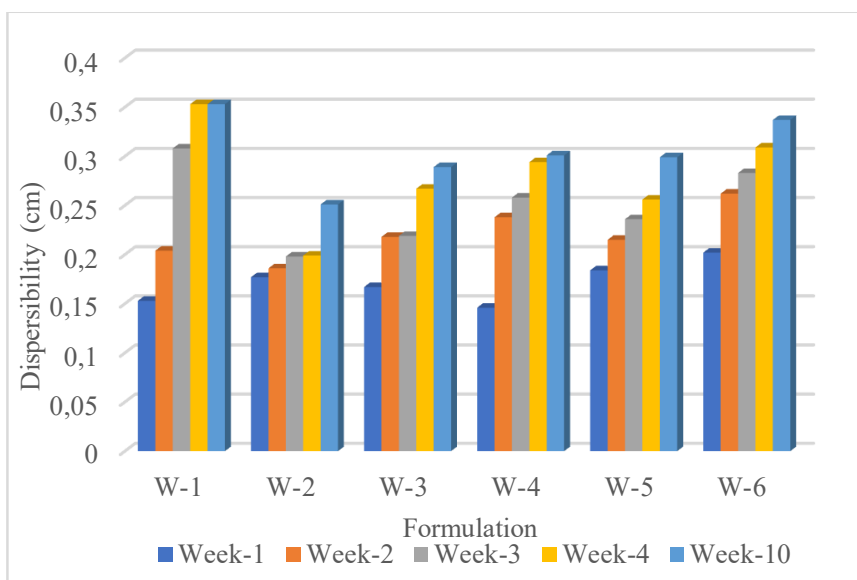

Fig. 11 Dispersibility stability of the wipe hand sanitizer

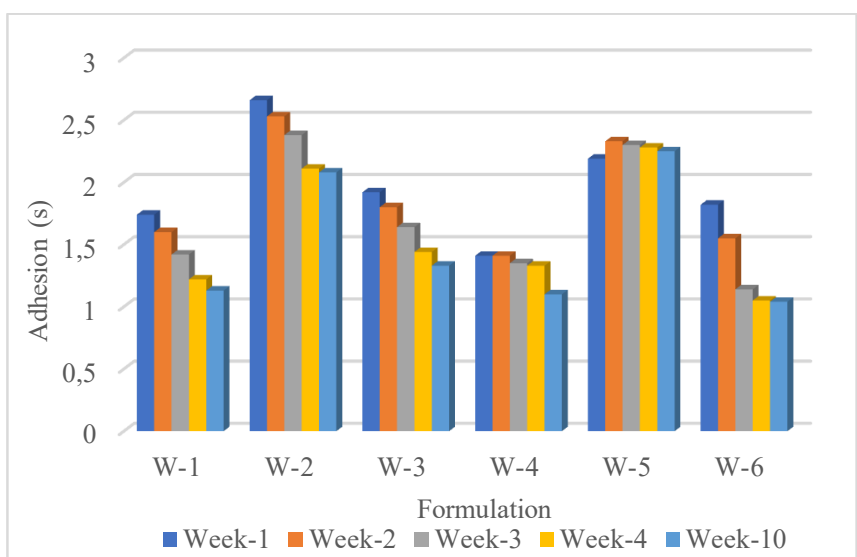

Fig. 12 Adhesion stability of the wipe hand sanitizer 


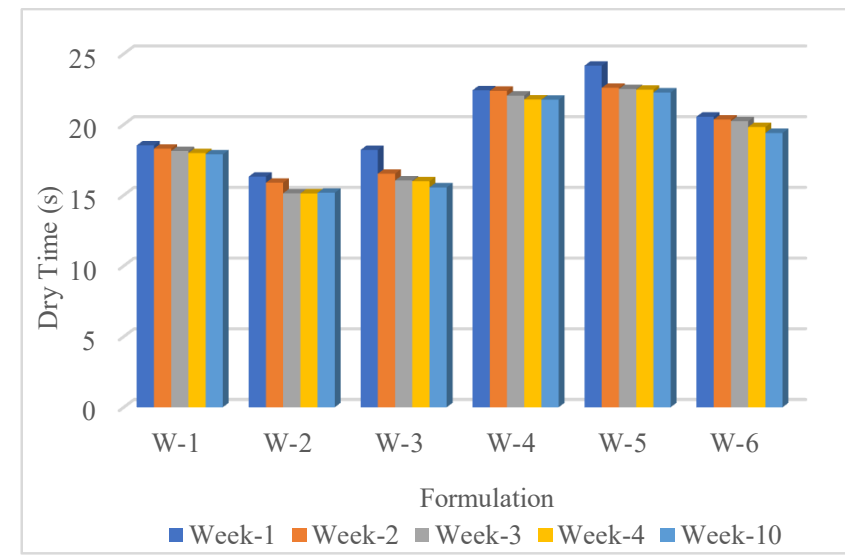

Fig. 13 Dry time of the wipe hand sanitizer

At a temperature of $\pm 30{ }^{\circ} \mathrm{C}$ for 10 weeks, all formulations of gels and wipes hand sanitizer showed fairly high homogeneity stability. Based on the data from the homogeneity stability test results, all gel and wipe hand sanitizer formulations showed good gel homogeneity, which was indicated by the uniform dispersion of the gel or not observing the formation of granules on one side.

The stability of density, viscosity, dispersibility, adhesion and dry time of gel and hand sanitizer products are closely related. After 10 weeks of storage at $\pm 30^{\circ} \mathrm{C}$, although not significant, an increase in density was detected. This is closely related to the increase in the viscosity of sanitary products under particular conditions. The storage of sanitary products at room temperature tends to be high triggers the breaking of water trapped in carbomers so that the $\mathrm{OH}$ group content decreases and has an impact on reducing the $\mathrm{pH}$ value to become more acidic. In addition, viscosity is influenced by the level of acidity of a preparation which affects the number of ionized carboxyl groups decreasing so that it repels the carboxyl groups, which can cause the development of the carbomer structure to decrease and cause a decrease in the viscosity of the gel preparation [50], [51]. Thus, the viscosity becomes a function of time, where the viscosity decreases with time. In addition, changes in viscosity cause changes in dispersibility, adhesion, and dry time. In general, a decrease in viscosity leads to an increase in dispersibility, a decrease in adhesion, and a decrease in a dry time.

\section{J. Anti-microbial Activity}

Eschericia coli, Staphylococcus aureus, and salmonella thypimurium are commonly found in water [52]. Water media is one distribution media that has much contact with humans. Eschericia coli is a gram-negative rod-shaped bacteria that can cause foodborne outbreaks [53]. This is indicated by the ability to survive on the surface for a long time so that handling is needed that can reduce the presence of these contaminants [54]. Several things have been done in handling, namely through heating, ultrasound, ultraviolet-C. The addition of sodium hypochlorite, sodium benzoate, potassium sorbate, potassium dioxide, peracetic acid, copper sulfate, vanilla, sodium bicarbonate, and so on. In addition, the existence of products in the form of sanitization is a critical step to reduce microorganism contaminants [55], [56]. E. coli is a type of bacteria that normally lives in the intestines of humans and animals. E. coli can cause intestinal infection symptoms, including diarrhea, stomach pain, and fever. More severe cases can cause bloody diarrhea, dehydration, or even kidney failure. E. coli can be transmitted and spread from person to person via "oral-fecal route" such as eating contaminated food, drinking contaminated water, or touching the mouth with contaminated hands containing the diseasecausing strain of E. Coli [57], [58].

Staphylococcus aureus is the main pathogenic bacteria in humans, so almost everyone has experienced this bacterial infection with different degrees of severity. Staphylococcus aureus is a bacterium in the form of Gram-positive cocci which is grouped in the fourth rank of $3.6 \%$ of Streptococcus alba (10.7\%); Stretococcus Alfa (10.7\%); and Candida (7.1\%) [59]. Staphylococcus aureus, a bacterial pathogen that causes a variety of diseases in humans, is the most common cause of skin and soft tissue infection (SSTI) globally [60], [61]. In humans, it is responsible for a range of illnessesfrom mild skin disorders to invasive infections and life-threatening in hospital settings [62]. It can also be community-acquired, causing skin and soft tissue infections with moderate tosevere symptoms in healthy and younger people [63]. In animals, S.aureus infections impact livestock, companion animals and somewild animals [64]-[66].

Salmonella Typhimurium is a foodborne pathogen, the main etiological agent in Salmonellosis. Salmonellosis is a bacteria that is found in various types of food such as cheese, fruits and vegetables with less cleaning process, and meat. However, egg and chicken meat based products mostly contain S. Enteritidis and S. Typhimurium bacteria [67]. The mechanism for the spread of salmonella in the human body is similar to the spread of bacteria e. coli, namely through the "oral-fecal route" by attacking the surface of the intestine. naturally the immune system will respond by producing oxygen radicals to kill salmonella bacteria.

The test results for the antibacterial activity of gel hand sanitizer with best qualification (G3) showed good results on the three tested bacteria, namely Escherichia coli, Staphyloccus aureus, and Salmonella. The results of the antibacterial activity test against Escherichia coli, Staphyloccus aureus, and Salmonella are presented in Table 7.

TABLE VII

THE RESULTS OF THE ANTIBACTERIAL ACTIVITY TEST OF THE GEL HAND SANITIZER

\begin{tabular}{llll}
\hline No & Isolate & Activity & Type \\
\hline 1 & Escherichia coli & Have activity & \\
2 & Staphylococcus & Have activity & Gel Hand \\
& aureus & & Sanitizer \\
3 & Salmonella & Have activity & \\
4 & Escherichia coli & Have activity & \\
5 & Staphylococcus & Have activity & Wipe Hand \\
& aureus & Sanitizer \\
6 & Salmonella & Have activity & \\
\hline
\end{tabular}

The results of the antibacterial activity test using the liquid diffusion method by planting on NA agar will show the test parameters in the form of the presence or absence of antibacterial activity. The results of the antibacterial activity test for positive control, namely the $\mathrm{X}$ brand hand sanitizer gel, showed the presence of antibacterial activity in Escherichia coli, Staphylococcus aureus, and Salmonella. The best hand sanitizer gel formulation showed the presence of 
antibacterial activity for Escherichia coli, Staphylococcus aureus, and Salmonella. While the negative control, namely the hand sanitizer gel formulation without active ingredients (alcohol) did not show clear zones in Escherichia coli, Staphylococcus aureus, or Salmonella isolates. These results prove that the antibacterial activity of hand sanitizer gel products is produced by alcoholic active ingredients and not other ingredients.

In general, the antibacterial activity test results of wipe hand sanitizer products against Escherichia coli, Staphylococcus aureus, and Salmonella showed similar results to the gel. In particular, the best quality hand sanitizer (W3) showed the presence of antibacterial activity for Escherichia coli, Staphylococcus aureus, and the presence of antibacterial activity for Salmonella. Regarding negative control of antibacterial activity, the formulation of hand sanitizer wipes without the active ingredient (alcohol) also did not show clear zones in Escherichia coli, Staphylococcus aureus, or Salmonella isolates. Thus, it is proven that the antibacterial activity of tissue hand sanitizers is produced by the active ingredient (alcohol).

A good hand sanitizer antibacterial activity against bacteria strains of E. coli that can suppress the immune response is EHEC (Enterohaemorrhagic Escherichia coli). EHEC can suppress the immune response by releasing the Shiga toxin produced, causing microvascular blockage, which can lead to bloody or bloodless diarrhea, hemorrhagic colitis and hemolytic uremic syndrome [68]-[70]. The existence of good hand-sanitizer antibacterial activity against Staphylococcus aureus bacteria which can surpress immunity against bacteria in the broadest and most resistant strains of Staphlococcus aureus bacteria against methicillin and against all $\beta$-lactams [66], [71]. The antibacterial activity of a good hand sanitizer against Salmonella bacteria can suppress the immune response by producing oxygen radicals to kill salmonella bacteria. Apart from being repelled by the body's immune response, the spread of salmonella bacteria can be prevented by inhibiting the spread of salmonella battery activity through the "oral-fecal route" by maintaining the cleanliness of the hands' surface can have direct oral contact [72].

Overall analysis results, both physico-chemical and antimicrobial activity, show the best qualifications for the G-3 and $\mathrm{W}-3$ formulations with bioethanol as active ingredients. The high qualification of bioethanol-based gel and wipe hand sanitizer products promises the availability of alternative sanitation products that are functional and easy and comfortable to use.

\section{CONCLUSIONS}

Diversification of hand sanitizer products has been carried out through the manufacture of gels and wipes hand sanitizer. The use of a number of alcohol-based active ingredients, including ethanol, isopropanol, biethanol, bioethanol-ethanol, bioethanol-isopropanol, and ethanol-isopropanol were evaluated to obtain the best formulation with the best characteristics and anti-microbial activity. The evaluation results showed the effect of the type of alcoholic active substance on the characteristics and anti-microbial activity againts Eschericia coli, Staphylococcus aureus, and Salmonella.
Overall analysis of physicochemical and anti-microbial activity shows the best qualifications for the G-3 and W-3 formulations with bioethanol as active ingredients. The acidity $(\mathrm{pH})$ of the G-3 and $\mathrm{W}-3$ hand sanitizers that are close to the $\mathrm{pH}$ of the skin will ensure minimum irritation. Adequate viscosity and dispersibility will ensure disinfection of large surface areas prior to evaporation. The minimum adhesion of the product and the short drying time increases user comfort. Good stability will ensure maximum protection against microbes for a certain range of time.

\section{ACKNOWLEDGMENT}

The authors thank the Ministry of Education and Culture of the Republic of Indonesia for providing financial support through national competitive research grants. We are obliged to the Department of Chemistry, Faculty of Mathematics and Natural Sciences Universitas Negeri Surabaya for providing research facilities support.

\section{REFERENCES}

[1] A. P. Golin, D. Choi, and A. Ghahary, "Hand sanitizers: A review of ingredients, mechanisms of action, modes of delivery, and efficacy against coronaviruses," Am. J. Infect. Control, vol. 48, no. 9, pp. 10621067, 2020, doi: 10.1016/j.ajic.2020.06.182.

[2] WHO, "World Health Organisation. Guidelines on Hand Hygiene in Health Care: First Global Patient Safety Challenge Clean Care Is Safer Care," World Health, p. 12, 2009.

[3] A. Mahmood et al., "COVID-19 and frequent use of hand sanitizers; human health and environmental hazards by exposure pathways," Sci. Total Environ., vol. 742, p. 140561, 2020, doi: 10.1016/j.scitotenv.2020.140561.

[4] R. A. Leslie, S. S. Zhou, and D. R. Macinga, "Inactivation of SARSCoV-2 by commercially available alcohol-based hand sanitizers," Am. J. Infect. Control, vol. 00, pp. 1-2, 2020, doi: 10.1016/j.ajic.2020.08.020.

[5] C. Osei-Asare et al., "Managing Vibrio cholerae with a local beverage: preparation of an affordable ethanol based hand sanitizer," Heliyon, vol. 6, no. 1, p. e03105, 2020, doi: 10.1016/j.heliyon.2019.e03105.

[6] O. M.J., The Merck Index, an Encyclopedia of Chemicals, Drugs, and Biologicals - NMR solvent data Charts. Whitehouse: Merck and Co., Inc, 2006.

[7] Doe, Hand Sanitizers and Wipes on High Demand. Accra, Ghana: The General Telegraph, 2014.

[8] W. Guan et al., "Clinical Characteristics of Coronavirus Disease 2019 in China," N. Engl.J. Med., vol. 382, no. 18, pp. 1708-1720, 2020, doi: 10.1056/nejmoa2002032.

[9] Public Health, Methanol Toxicological overview. England, 2016.

[10] M. Ghannoum, R. S. Hoffman, J. B. Mowry, and V. Lavergne, "Trends in toxic alcohol exposures in the United States from 2000 to 2013: A focus on the use of antidotes and extracorporeal treatments," Semin. Dial., vol. 27, no. 4, pp. 395-401, 2014, doi: 10.1111/sdi.12237.

[11] S. Zakharov et al., "Czech mass methanol outbreak 2012: Epidemiology, challenges and clinical features," Clin. Toxicol., vol. 52, no. 10, pp. 1013-1024, 2014, doi: 10.3109/15563650.2014.974106.

[12] R. H. K. Thanacoody et al., "Management of poisoning with ethylene glycol and methanol in the UK: A prospective study conducted by the National Poisons Information Service (NPIS)," Clin. Toxicol., vol. 54, no. 2, pp. 134-140, 2016, doi: 10.3109/15563650.2015.1116044.

[13] M. Rostrup et al., "The methanol poisoning outbreaks in Libya 2013 and Kenya 2014," PLoS One, vol. 11, no. 3, pp. 1-10, 2016, doi: 10.1371/journal.pone.0152676.

[14] R. Paasma, K. E. Hovda, A. Tikkerberi, and D. Jacobsen, "Methanol mass poisoning in Estonia: Outbreak in 154 patients," Clin. Toxicol., vol. 45 , no. 2 , pp. 152-157, 2007, doi: 10.1080/15563650600956329.

[15] J. H. Choi et al., "Neurological complications resulting from non-oral occupational methanol poisoning," J. Korean Med. Sci., vol. 32, no. 2, pp. 371-376, 2017, doi: 10.3346/jkms.2017.32.2.371.

[16] R. K. Law, S. Sheikh, A. Bronstein, R. Thomas, H. A. Spiller, and J. G. Schier, "Incidents of potential public health significance identified using national surveillance of US poison center data (2008-2012)," Clin. Toxicol., vol. 52, no. 9, pp. 958-963, 2014, doi: 
10.3109/15563650.2014.953171.

[17] M. A. K. L. Dissanayake, H. K. D. W. M. N. R. Divarathne, C. A. Thotawatthage, C. B. Dissanayake, G. K. R. Senadeera, and B. M. R. Bandara, "Dye-sensitized solar cells based on electrospun polyacrylonitrile (PAN) nanofibre membrane gel electrolyte," Electrochim. Acta, vol. 130, pp. 76-81, 2014, doi: 10.1016/j.electacta.2014.02.122

[18] E. L. Larson, B. Cohen, and K. A. Baxter, "Analysis of alcohol-based hand sanitizer delivery systems: Efficacy of foam, gel, and wipes against influenza A (H1N1) virus on hands," Am. J. Infect. Control, vol. 40, no. 9, pp. 806-809, 2012, doi: 10.1016/j.ajic.2011.10.016.

[19] J. Wijaya, "Formulasi Sediaan Gel Hand Sanitizer Dengan Bahan Aktif Triklosan 1,5\% dan 2\%," Calyptra, vol. 2, no. 1, pp. 1-14, 2013.

[20] R. C Rowe, P. J Sheskey, and M. E Quinn, Handbook of Pharmacueical Excipients. 2009.

[21] N. S. Wani, A. K. Bhalerao, V. P. Ranaware, and R. Zanje, "Formulation and evaluation of herbal sanitizer," Int. J. PharmTech Res., vol. 5, no. 1, pp. 40-43, 2013.

[22] E. L. Larson, "APIC guidelines for handwashing and hand antisepsis in health care settings," AJIC Am. J. Infect. Control, vol. 23, pp. 251269, 1995, doi: 10.1016/0196-6553(95)90070-5

[23] C. Pasquini, M. C. Hespanhol, K. A. M. L. Cruz, and A. F. Pereira, "Monitoring the quality of ethanol-based hand sanitizers by low-cost near-infrared spectroscopy," Microchem. J., vol. 159, p. 10542, 2020 doi: 10.1016/j.microc.2020.105421.

[24] A. Asngad and A. R. Bagas, "Kualitas pembersih Tangan Hand Sanitizer," J. bioeksperimen, vol. 4, no. 2, pp. 61-70, 2018, doi: 10.23917/bioeksperimen.v4i2.6888.

[25] A. Padsalgi, D. Jain, S. Bidkar, D. Harinarayana, and V. Jadhav, "Preparation and evaluation of hand rub disinfectant," Asian J. Pharm. vol. 2, no. 1, pp. 18-21, 2008, doi: 10.4103/0973-8398.41559.

[26] M. M. Nerandzic, C. Thriveen Sankar, P. Setlow, and C. J. Donskey, "A Cumulative spore killing approach: Synergistic sporicidal activity of dilute peracetic acid and ethanol at low $\mathrm{pH}$ against Clostridium difficile and Bacillus subtilis spores," Open Forum Infect. Dis., vol. 3 , no. 1, pp. 1-7, 2016, doi: 10.1093/ofid/ofv206

[27] Yusuf, N. Arfiyanti, and Fatmawaty, "Pengaruh Isopropil Myristat Sebagai Bahan Peningkat Penetrasi Terhadap Laju Difusi Krim Pemutih Ekstrak Etanol Daun Murbei (Morus alba.L)," J. Ilm Manuntung, vol. 3, no. 1, pp. 43-51, 2017.

[28] H. M. Al-Yousef and M. Amina, "Essential oil of Coffee arabica L. Husks: A brilliant source of antimicrobial and antioxidant agents.," Biomed. Res., vol. 29, no. 1, pp. 174-180, 2018, doi 10.4066/biomedicalresearch.29-17-867.

[29] Y. Shimizu-Onda et al. "The virucidal effect against murine norovirus and feline calicivirus as surrogates for human norovirus by ethanolbased sanitizers," J. Infect. Chemother., vol. 19, no. 4, pp. 779-781, 2013, doi: 10.1007/s10156-012-0516-2.

[30] A. S. Milala, M. Sofyan, and M. Wahjudi, "The Formulation and Antibacterial Activity of Hand Sanitizer Gels Containing Lampes (Ocimum sanctum L.) Leaves Extract as An Active Compound," Inatradmed.pp. 1--7, 2014.

[31] K. Kulthanan, P. Maneeprasopchoke, S. Varothai, and P. Nuchkull, "The pH of antiseptic cleansers," Asia Pac. Allergy, vol. 4, no. 1, p. 32 2014, doi: 10.5415/apallergy.2014.4.1.32.

[32] S. Titaley, Fatimawali, and W. A. Lolo, "Formulasi dan Uji Efektifitas Sediaan Gel Ekstra Etanol Daun Mangrove Api-Api (Avicennia marina) Sebagai Antiseptik Tangan," Pharmacon, vol. 3, no. 2, pp. 99106, 2014, doi: 10.35799/pha.3.2014.4781

[33] S. Wijana, E. P. Pratama, N. L. Rahmah, and M. Arwani, "Hand sanitizer formulation using orange peel essential oil," IOP Conf. Ser. Earth Environ. Sci., vol. 524, no. 1, p. 012021, 2020, doi: $10.1088 / 1755-1315 / 524 / 1 / 012021$

[34] M. A. Putri, M. E. Saputra, I. N. Amanah, and V. A. Fabiani, "Uji Sifat Fisik Sediaan Gel Handsanitizer Ekstrak Daun Pucuk Idat (Cratoxylum Glaucum)," Pros. Semin. Nas. Penelit. dan Pengabdi. Pada Masy., vol. 3, pp. 39-40, 2019, doi: doi.org/10.33019/snppm.v3i0.1309.

[35] M. T. Islam, N. Rodríguez-Hornedo, S. Ciotti, and C. Ackermann, "Rheological characterization of topical carbomer gels neutralized to different pH," Pharm. Res., vol. 21, no. 7, pp. 1192-1199, 2004, doi: 10.1023/B:PHAM.0000033006.11619.07.

[36] A. F. Tsabitah and D. A. . Zulkarnain, A.K. Wahyuningsih, M.S.H Nugrahaningsih, "Optimasi Carbomer, Propilen Glikol, dan Trietanolamin Dalam Formulasi Sediaan Gel Ekstrak Etanol Daun Kembang Bulan (Tithonia diversifolia)," Maj. Farm., vol. 16, no. 2 , pp. 111-118, 2020, doi: 10.22146/farmaseutik.v16i2.45666.
[37] R. Hirose et al., "Viscosity is an important factor of resistance to alcohol-based disinfectants by pathogens present in mucus," Sci. Rep., vol. 7, no. 1, pp. 1-12, 2017, doi: 10.1038/s41598-017-13732-2.

[38] WHO, WHO guidelines on hand hygeine in health care (advanced draft): Global Patient safety Challenge 2005-2006: Clean Care is Safer Care. Switzerland: WHO Press, 2006.

[39] A. F. De Aceituno et al., "Ability of hand hygiene interventions using alcohol-based hand sanitizers and soap to reduce microbial load on farmworker hands soiled during harvest," J. Food Prot., vol. 78, no. 11, pp. 2024-2032, 2015, doi: 10.4315/0362-028X.JFP-15-102.

[40] S. Shalaby and M. Shukr, "The Influence of the Type and Concentration of Alcohol on the Rheological and Mucoadhesive Properties of Carpobol 940 Hydroalcoholic Gels.," Der Pharm. Sin., vol. 2, no. 6, pp. 161-171, 2011

[41] S. Ulaen, Y. Banne, and R. Suatan, "Pembuatan Salep Anti Jerawa Dari Ekstrak Rimpang Temulawak (Curcuma Xanthorrhiza Roxb.)," $J$. Ilm. Farm. Poltekkes Manad., vol. 3, no. 2, pp. 45-49, 2012.

[42] M. Sompie, S. E. Surtijono, J. H. W. Pontoh, and N. N. Lontaan, "The Effects of Acetic Acid Concentration and Extraction Temperature on Physical and Chemical Properties of Pigskin Gelatin," Procedia Food Sci., vol. 3, pp. 383-388, 2015, doi: 10.1016/j.profoo.2015.01.042.

[43] R. Riski, A. Nur, A. Akbar, and Nurindasari, "Formula krim pemutih dari fitosom ekstrak daun murbei (Morus alba L.)," JF FIK UINAM, vol. 5, no. 4, pp. 233-238, 2017, doi: 10.24252/.v5i4.4464

[44] N. W. R. Martyasari, Y. Andayani, and W. Hajrin, "Optimisation of hand sanitiser gel formula of Tekelan leaves extract (Chromolaena odorata) using simplex lattice design method," Bali Med. J., vol. 8, no. 3, pp. 769-773, 2019, doi: 10.15562/bmj.v8i3.1598.

[45] I. Hapsari, A. Rosyadi, and R. Wahyuningrum, "Optimasi Kombinasi Minyak Atsiri Bunga Kenanga Dengan Herba Kemangi Dalam Ge Sebagai Repelan Nyamuk Aedes aegypti Dengan Metode Simplex Lattice Design," Universitas Muhammadiyah Purwwokerto, 2014.

[46] N. Octavia, "Formulasi Sediaan Gel Hand Sanitizer Minyak Atsiri Pala (Myristica fragransHoutt.): Uji Stabilitas Fisik Dan Uji Aktivitas Antibakteri Terhadap Bakteri Staphylococcus aureus," Universitas Muhammadiyah Surakarta, 2016.

[47] Z. Azkiya, H. Ariyani, and T. Nugraha, "Evaluasi Sifat Fisik Krim Ekstrak Jahe Merah (Zingiber officinale Rosc. var. rubrum) sebagai Antinyeri," J. Curr. Pharm. Sci., vol. 1, no. 1, pp. 12-18, 2017.

[48] M. E. Nuriani, M. Jufri, and Azizahwati, "Formulasi dan uji stabilitas fisik gel dari ekstrak methanol bekatul (Oryza sativa L.) sebagai inhibisi aktivitas tirosinase," JFarmasi UI, vol. 4, no. 1, pp. 21-27, 2013

[49] E. S. Kuncari, "Evaluasi, uji stabilitas fisik dan sineresisi sediaan gel yang mengnadung minoksidil, apigenin dan perasan herba seledri (Apium graveolens L.," Bul. Penelit. Kesehat., vol. 42, no. 4, pp. 213 222,2014

[50] R. Hidayaturahmah and S. Harimurti, "Pengaruh Variasi Konsentrasi Karbomer Sebagai Gelling Agent Terhadap Viskositas dan pH Sediaan Gel Antiseptik Ekstrak Etanolik Daun Sirih Merah," Fakltas Kedokt. dan Ilmu Kesehat., vol. 1, no. 5, pp. 1-8, 2016.

[51] A. Asngad, A. B. R, and N. Nopitasari, "Kualitas Gel Pembersih Tangan (Handsanitizer) dari Ekstrak Batang Pisang dengan Penambahan Alkohol, Triklosan dan Gliserin yang Berbeda Dosisnya," Bioeksperimen J. Penelit. Biol., vol. 4, no. 2, pp. 61-70, 2018, doi: 10.23917/bioeksperimen.v4i2.6888.

[52] J. yi Wu, L. Gu, Z. lin Hua, X. qing Li, Y. Lu, and K. jian Chu, "Effects of Escherichia coli pollution on decomposition of aquatic plants: Variation due to microbial community composition and the release and cycling of nutrients," J. Hazard. Mater., vol. 401, pp. 1-10, 2021, doi: 10.1016/j.jhazmat.2020.123252

[53] D. Millan-Sango, A. McElhatton, and V. P. Valdramidis, "Determination of the efficacy of ultrasound in combination with essential oil of oregano for the decontamination of Escherichia coli on inoculated lettuce leaves," Food Res. Int., vol. 167, pp. 145-154, 2015, doi: 10.1016/j.foodres.2014.11.001.

[54] L. Guo et al., "The antibacterial mechanism of ultrasound in combination with sodium hypochlorite in the control of Escherichia coli," Food Res. Int., vol. 129, pp. 1-39, 2020, doi: 10.1016/j.foodres.2019.108887

[55] R. R. Elano, T. Kitagawa, M. L. Bari, S. Kawasaki, S. Kawamoto, and Y. Inatsu, "Comparison of the effectiveness of acidified sodium chlorite and sodium hypochlorite in reducing Escherichia coli," Foodborne Pathog. Dis., vol. 7, no. 12, pp. 1481-1489, 2010, doi: 10.1089/fpd.2010.0595.

[56] J. Li, T. Ding, X. Liao, S. Chen, X. Ye, and D. Liu, "Synergetic Effect Of Ultrasound and Slighltly Acidic Electrolyzed Water Againts 
Staphlococcus Aureus Evaluated By Flow Cytometry And Electron Microscopy," Ultrason. Sonochemistry, vol. 38, pp. 711-719, 2017.

[57] A. Pietrangelo, "E. coli Infection," Healthline, vol. 7, no. 26, pp. 1-5, 2015.

[58] WHO, "E. Coli," World Health Organization, 2018.

[59] M. Ngajow, J. Abidjulu, and V. S. Kamu, "Pengaruh Antibakteri Ekstrak Kulit Batang Matoa (Pometia pinnata) terhadap Bakteri Staphylococcus aureus secara In vitro," J. MIPA, vol. 2, no. 2, pp. $128-$ 132, 2013, doi: 10.35799/jm.2.2.2013.3121

[60] S. Esposito, S. Noviello, and S. Leone, "Epidemiology and microbiology of skin and soft tissue infections," Curr. Opin. Infect. Dis., vol. 29, pp. 109-115, 2016, doi: 10.1097/QCO.0000000000000239.

[61] C. Yang et al., "Antibody-mediated protection against Staphylococcus aureus dermonecrosis: synergy of toxin neutralization and neutrophil recruitment," J. Invest. Dermatol., pp. 1-42, 2020, doi: 10.1016/j.jid.2020.09.001

[62] A. J. McCarthy and J. A. Lindsay, "Genetic variation in staphylococcus aureus surface and immune evasion genes is lineage associated: Implications for vaccine design and host-pathogen interactions," BMC Microbiol., vol. 10, p. 173, 2010, doi: 10.1186/1471-2180-10-173.

[63] M. Z. David and R. S. Daum, "Community-associated methicillinresistant Staphylococcus aureus: Epidemiology and clinical consequences of an emerging epidemic," Clin. Microbiol. Rev., vol. 23, no. 3, pp. 616-687, 2010, doi: 10.1128/CMR.00081-09.

[64] A. J. Mccarthy, J. A. Lindsay, and A. Loeffler, "Are all meticillinresistant Staphylococcus aureus (MRSA) equal in all hosts? Epidemiological and genetic comparison between animal and human MRSA,"Vet. Dermatol., vol. 23, no. 4, pp. 53-54, 2012, doi: 10.1111/j.1365-3164.2012.01072.x.

[65] I. Spiliopoulou and E. Petinaki, "Methicillin-resistant Staphylococcus aureus colonization and infection risks from companion animals: current perspectives," Vet. Med. Res. Reports, vol. 6, pp. 373-382, 2015, doi: 10.2147/vmrr.s91313.

[66] C. Ngassam-Tchamba et al., "In vitro and in vivo assessment of phage therapy against Staphylococcus aureus causing bovine mastitis," $J$ Glob. Antimicrob. Resist., vol. 22, pp. 762-770, 2020, doi: 10.1016/j.jgar.2020.06.020.

[67] A. N. F. de Melo et al., "Changes in thermo-tolerance and survival under simulated gastrointestinal conditions of Salmonella Enteritidis PT4 and Salmonella Typhimurium PT4 in chicken breast meat after exposure to sequential stresses," Int. J. Food Microbiol., vol. 251, pp. 15-23, 2017, doi: 10.1016/j.ijfoodmicro.2017.03.022.

[68] D. A. Vilte et al., "Reduced faecal shedding of Escherichia coli O157:H7 in cattle following systemic vaccination with $\gamma$-intimin C280 and EspB proteins," Vaccine, vol. 29, no. 23, pp. 3962-3968, 2011, doi: 10.1016/j.vaccine.2011.03.079.

[69] M. P. Stevens, P. M. van Diemen, F. Dziva, P. W. Jones, and T. S Wallis, "Options for the control of enterhaemorrhagic Escherichia coli in ruminants," Microbiology, vol. 148, pp. 3767-3778, 2002, doi: 10.1099/00221287-148-12-3767.

[70] E. Kieckens, J. Rybarczyk, R. W. Li, D. Vanrompay, and E. Cox, "Potential immunosuppressive effects of Escherichia coli O157: H7 experimental infection on the bovine host," BMC Genomics, vol. 17 no. 1 , pp. 2-15, 2016, doi: 10.1186/s12864-016-3374-y.

[71] C. A. Arias and B. E. Murray, "Antibiotic-Resistant Bugs in the 21st Century - A Clinical Super-Challenge," N. Engl. J. Med., vol. 360, no. 5, pp. 439-443, 2009, doi: 10.1056/nejmp0804651.

[72] P. Brown, "Salmonella outwits immune system," Futurity, 2010. . 